\title{
Conservative Surgical Treatment of Benign Parotid Tumors: Extracapsular Dissection
}

\author{
Sung Joon Park ${ }^{1}(\mathbb{D})$ and Woo-Jin Jeong ${ }^{2}$ (D) \\ ${ }^{1}$ Department of Otorhinolaryngology-Head and Neck Surgery, Yeouido St. Mary's Hospital, College of Medicine, The Catholic University \\ of Korea, Seoul; and ${ }^{2}$ Department of Otorhinolaryngology-Head and Neck Surgery, Seoul National University Bundang Hospital, Seoul \\ National University College of Medicine, Seongnam, Korea
}

\section{양성 이하선 종양의 보존적 수술적 치료법: 피막 외 절제술}

박 성 준 ${ }^{1}$ 정 우 진 ${ }^{2}$

가톨릭대학교 의과대학 여의도성모병원 이비인후과학교실, ${ }^{1}$ 서울대학교 의과대학 분당서울대병원 이비인후과학교실 ${ }^{2}$

\author{
Received February 27, 2019 \\ Revised May 8, 2019 \\ Accepted May 24, 2019 \\ Address for correspondence \\ Woo-Jin Jeong, $\mathrm{MD}, \mathrm{PhD}$ \\ Department of \\ Otorhinolaryngology-Head \& \\ Neck Surgery, \\ Seoul National University \\ Bundang Hospital, \\ 82 Gumi-ro 173 beon-gil, \\ Bundang-gu, Seongnam 13620, Korea \\ Tel $+82-31-787-7407$ \\ Fax $+82-31-787-4057$ \\ E-mailsafar@snubh.org
}

Parotid tumor resection, parotidectomy, is a surgical procedure that requires considerable experience from surgeons in most of the cases because of the risk of facial nerve damage. In addition, it is often times difficult to identify and preserve the facial nerve during the procedure, because it requires removal of a considerable amount of normal parotid tissue even when it is not related to the location of the tumor itself. Post-operative cosmetic problems and complications associated with inevitable removal of the normal parotid gland tissue cannot be ignored. For these reasons, parotidectomy has been evolved over the years to ensure the oncological safety, avoid complications, and improve functional and cosmetic results. Recently, the use and importance of extracapsular dissection (ECD) has become more recognized because it is a more conservative surgical method than partial superficial parotidectomy with preservation of facial nerve function, minimization of functional and cosmetic complications, and limited removal of unnecessary normal parotid gland tissue. Herein, we review the literatures related to ECD for benign parotid tumors and explain the efficacy of this emerging procedure based on the previous study results reported by the authors.

Korean J Otorhinolaryngol-Head Neck Surg 2019;62(6):317-22

\section{서 론}

이하선 종양은 모든 두경부 종양의 약 $3 \%$ 정도를 차지하 며,2) 이하선 종양 절제 수술은 대부분의 경우 안면신경의 손상 위험이 높아 외과의사들에게 상당한 경험을 요구하는 수술이다. 이하선 종양 절제술 중 안면 신경을 식별하고 보존 하기 위해서는 종양 자체의 위치와 관련이 없거나 멀리 있더 라도 상당한 양의 정상 이하선 조직을 박리해야 하기 때문에 시간이 많이 걸리고, 안면신경의 주간(main trunk)과 분지를

This is an Open Access article distributed under the terms of the Creative Commons Attribution Non-Commercial License (https://creativecommons.org/licenses/by-nc/4.0) which permits unrestricted non-commercial use, distribution, and reproduction in any medium, provided the original work is properly cited.
모두 박리함으로 인해 안면신경마비가 발생할 가능성이 높 으며, 정상 이하선 조직의 많은 부분을 함께 제거함에 따른 수술 후 미용적 문제, Frey 증후군 등의 합병증 역시 무시할 수 없다. ${ }^{3,4)}$ 그렇다고 안면 신경을 식별하지 않고 종양에 인접 한 부위의 정상 이하선 조직만을 제한적으로 절제하고 종양 을 제거할 경우 안면 신경에 손상을 줄 가능성이 남게 되어 이 또한 잠재적으로 부정적인 결과를 초래할 수 있다. ${ }^{5)}$

위와 같은 이유로 이하선 종양 절제 수술은 종양학적 안전 성을 보장하고 합병증을 피하며 기능적 및 미용적 결과를 향 상시키기 위해 시대를 거듭하며 발전해 왔다. ${ }^{6}$ 역사적으로 고 전적인 이하선 천엽절제술(conventional superficial parotidectomy, CSP)은 안면 신경의 안전성을 높이고 재발률을 현 

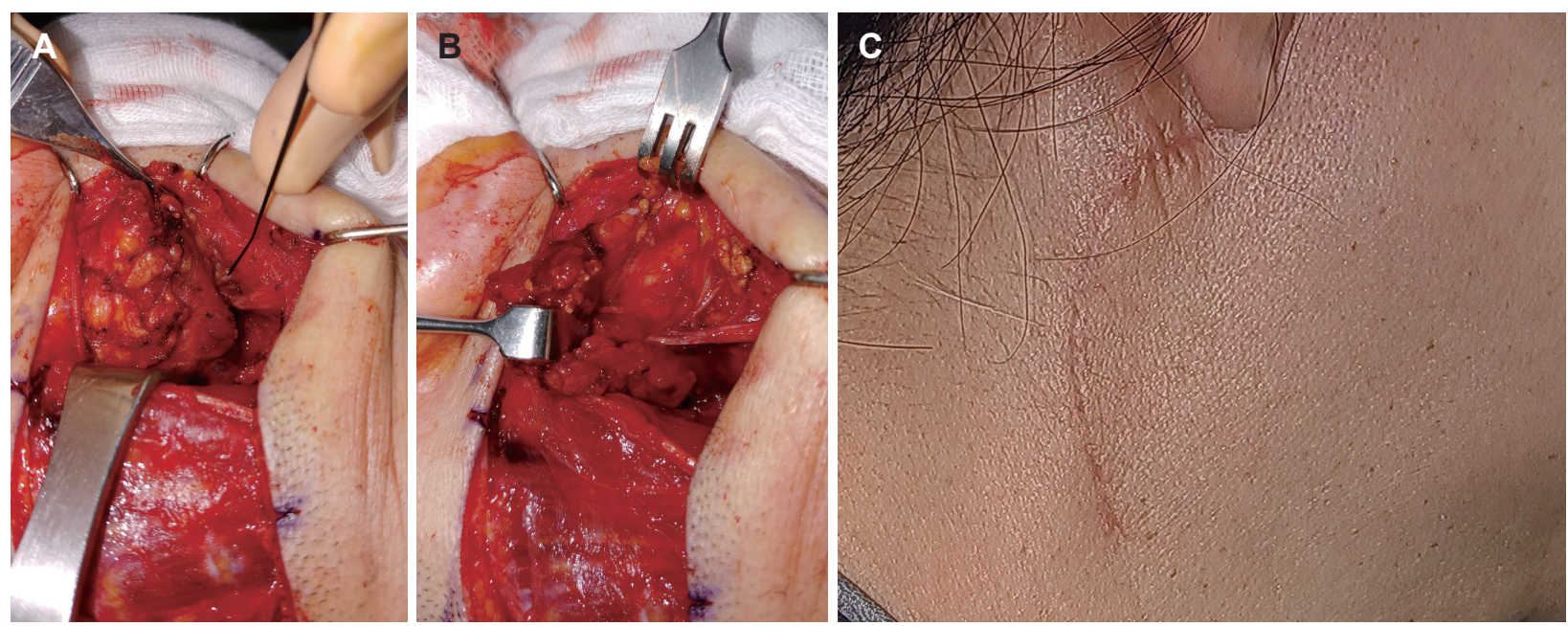

Fig. 1. Operative field (A, B) and postoperative result (C) of classic superficial parotidectomy for benign tumor of the parotid gland.
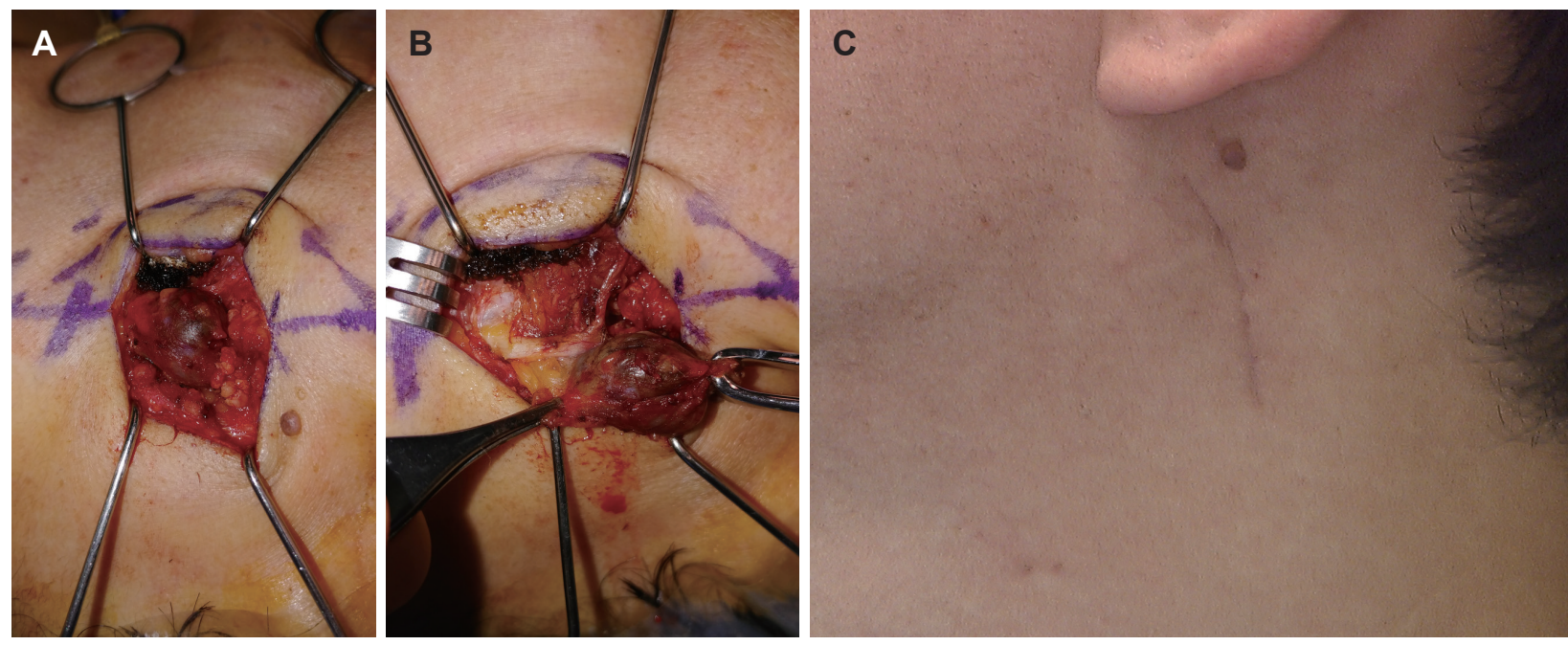

Fig. 2. Operative field (A, B) and postoperative result (C) of extracapsular dissection for benign tumor of the parotid gland.

저하게 향상시켜 이하선 양성 종양의 기본적인 수술적 치료 법으로 수십 년 동안 인정되어 왔다(Fig. 1). ${ }^{7.8}$ 그러나, 이하 선 부분천엽절제술(partial superficial parotidectomy, PSP) 의 후속 발달은 안면 신경의 식별 및 제한된 노출을 가능하 게 하고, $\mathrm{CSP}$ 와 유사한 결과를 나타내어 이하선 천엽 전체 를 반드시 다 제거하지 않아도 된다는 개념을 확립하는데 큰 기여를 하였다.

최근에는 양성 표재성 이하선 종양에 대하여 안면신경 기 능의 보존, 기능적 및 미용적 합병증의 최소화, 그리고 정상 이하선 조직의 제한적인 박리를 동반하는 PSP보다도 더 보 존적인 수술방법인 피막 외 절제술(extracapsular dissection, $\mathrm{ECD})$ 의 활용도 및 중요성에 대한 인식이 더 많아지고 있다(Fig. 2). 그러나, $\mathrm{ECD}$ 의 장기간의 종양학적 안전성은 여전히 불명확하며 수술 후 타액 배출 기능과 같은 기능적 결과에 대한 연구는 제한적으로만 시행되었다. 이에 본 종설
에서는 양성 이하선 종양의 수술적 치료를 위한 $\mathrm{ECD}$ 와 관 련된 문헌들을 고찰해보고, 본 교실에서 시행한 연구 결과를 보여주고자 한다.

\section{$\mathrm{ECD}$ 의 유용성과 안전성, 종양학적 결과에 대한 고찰}

기존의 연구들을 보면 다양한 국가의 다양한 연구팀에서 이하선의 양성 종양에 대한 수술적 치료 방법으로 $\mathrm{ECD}$ 와 $\mathrm{CSP}$ 및 PSP를 포함하는 이하선 천엽절제술(superficial parotidectomy, SP)을 비교 분석한 결과들을 보고한 바 있다.

Barzan과 $\mathrm{Pin}^{9}$ 이 384명의 양성 이하선 종양 환자들을 대 상으로 332 명에서는 $\mathrm{ECD}$ 를 그리고 52 명에서는 $\mathrm{SP}$ 를 시행 하여 발표한 결과에 따르면 $\mathrm{ECD}$ 를 시행한 환자에서 통계적 으로 유의하게 재발률이 낮았고 영구적인 안면신경마비, 침 
샘류, 그리고 Frey 증후군과 같은 합병증 또한 더 적은 것으 로 기술하였다. Dell'Aversana Orabona 등 ${ }^{10)}$ 도 232명의 양성 이하선 종양 환자들을 대상으로 평균 $2 \mathrm{~cm}$ 미만 크기의 종 양을 가진 176 명의 환자들에서 $\mathrm{ECD}$ 를, 평균 $3.5 \mathrm{~cm}$ 정도로 큰 종양을 가진 56 명의 환자들에서는 $\mathrm{SP}$ 를 시행하여 수술 결과를 비교하였고 $\mathrm{ECD}$ 는 $\mathrm{SP}$ 와 비교하였을 때 이하선 천엽 의 $2 \mathrm{~cm}$ 미만 크기의 양성 이하선 종양을 수술적으로 치료 하는데 충분히 효과적이며 수술 후 합병증이 적다는 결론을 도출하였다.

이러한 보고들과 다르게 $\mathrm{ECD}$ 와 $\mathrm{SP}$ 두 수술방법의 수술 과 연관된 여러 요인들 및 비용효율 분석을 시행한 결과에 따르면 $\mathrm{ECD}$ 를 시행한 환자군에서 $\mathrm{SP}$ 를 시행한 환자군과 비교하였을 때 전체 수술 시간, 마취 시간, 그리고 입원기간 이 유의하게 짧으면서 안면신경 기능저하, 대이개신경 감각장 애, 그리고 다른 수술과 관련된 합병증은 비슷하면서도 마취 및 수술 비용, 그리고 총 입원비가 유의하게 적었다고 보고한 바 있다. ${ }^{11}$

특정 양성 이하선 종양에서 수술 후 재발률과 관련하여서 도 Iro 등 ${ }^{12)}$ 이 76 명의 이하선 기원의 다형성종(pleomorphic adenoma, PA) 환자들만을 대상으로 $\mathrm{ECD}$ 를 시행하여 발표 한 결과에 따르면 평균 7.38년(5.05 10.52년) 동안 추적관찰 하였을 때 단 한 명의 환자에서도 재발하지 않았다고 보고한 바 있다. 또한 Lee 등기이 이하선 꼬리부위에 발생한 낭선림 프종(Warthin's tumor, WT) 환자 72명을 대상으로 40명의 환 자들에서는 $\mathrm{ECD}$ 를 그리고 32명의 환자들에서는 $\mathrm{SP}$ 를 시행 한 결과 $\mathrm{ECD}$ 를 시행하였을 때 유의하게 수술 시간이 짧았 고 더 적은 수의 환자에서 수술 후 안면신경 마비를 보였으 며 $\mathrm{SP}$ 를 시행 받은 1 명의 환자에서만 재발을 보였다고 발표 한 바 있다. Mantsopoulos 등 ${ }^{14}$ 은 추가로 이하선에 발생한 327 명의 WT 환자들을 대상으로 $\mathrm{ECD}$ 를 시행 후 평균 108.4 개월 추적관찰 한 결과 단방낭성 병변이 있었던 환자들과 비 교하였을 때 다방낭성 병변이 있었던 환자들에서 유의하게 동측의 후시성 종양이 발생한다고 발표한 바 있다.

이와 같이 $\mathrm{ECD}$ 의 유용성과 관련하여 발표된 다수의 긍정 적인 연구 결과들을 근거로 더 확실한 임상적 근거를 마련하 기 위한 체계적 문헌 고찰 및 메타분석 또한 시행되어 그 결 과가 보고된 바 있다. 2014년도에 Foresta 등 ${ }^{15)}$ 은 1152개의 문헌들을 고찰하여 123 개의 문헌들에서 보고된 결과들을 바탕으로 $\mathrm{ECD}$ 와 $\mathrm{SP}$ 사이의 재발률, 영구적인 안면신경 마 비율, 그리고 Frey 증후군의 발생률을 비교 분석하는 메타 분석 결과를 보고한 바 있다. 이 메타분석 결과에 따르면 PA 단독 및 $\mathrm{PA}$ 를 포함한 모든 이하선 양성종양에서 $\mathrm{SP}$ 를 시행 한 환자들보다 $\mathrm{ECD}$ 를 시행한 환자들에서 더 낮은 재발률을
보였고 PA만 따로 보았을 때 수술 후 영구적인 안면신경 마 비 및 Frey 증후군이 유의하게 더 적은 것으로 나타났다. 이 와 같은 연구 결과와 더불어 Xie 등히이 14 개의 코호트 연구 결과에 포함된 3194명의 환자들을 대상으로 시행한 메타분 석 결과에 따르면 양성 이하선 종양의 재발률에는 차이가 없 었으나 일시적 및 영구적인 안면신경 마비 및 Frey 증후군과 같은 수술 후 합병증의 경우에는 $\mathrm{ECD}$ 를 시행 받은 환자들 에서 $\mathrm{SP}$ 를 시행 받은 환자들과 비교하였 때 우월한 결과를 보여준 바 있다.

이렇듯 $\mathrm{ECD}$ 의 유용성에 대한 결과들이 보고되었음에도 불구하고 $\mathrm{ECD}$ 의 유용성에 대한 우려에 대한 목소리는 꾸준 히 있어 왔다. Barzan과 $\mathrm{Pin}^{9}$ 이 발표한 연구 결과의 경우 임 상적으로 간단히 완전제거가 가능한 환자들에서 $\mathrm{ECD}$ 를 그 리고 완전한 제거가 쉽지 않아 보이는 환자들에서 $\mathrm{SP}$ 를 시 행하였다고 언급하였으며, Dell'Aversana Orabona 등이이 발 표한 연구 결과의 경우에는 평균 $2 \mathrm{~cm}$ 미만 크기의 종양을 가진 환자들에서는 $\mathrm{ECD}$ 를 평균 $3.5 \mathrm{~cm}$ 정도로 큰 종양을 가진 환자들에서는 $\mathrm{SP}$ 를 시행한 것과 같이 기존의 연구 결 과들의 도출과정에서 표본선택의 편향(selection bias)이 있 을 수 밖에 없었음을 언급한 바 있다. 이와 같은 우려에 대한 대응으로 Mantsopoulos 등근 은 2017년도에 이하선의 양성 종양에 대한 수술적 치료로 $\mathrm{ECD}$ 만을 시행한 1359예의 수 술 결과를 후향적으로 분석하여 발표하였다. 이 연구보고에 서는 오직 5\%의 환자들에서만 일시적인 안면신경 마비가 발 생하였고 오직 $0.37 \%$ 에서만 영구적인 안면신경마비가 발생 하였고 4명의 PA 환자들에서만 재발을 보였다고 하며(재발 률 $0.87 \%) \mathrm{ECD}$ 의 비우월성을 증명할 수 없었다고 결론을 내렸다. ${ }^{17)}$ 이에 Quer 등ㄹ)은 같은 해에 모든 양성 이하선 종 양을 병리학적 진단, 종양의 크기, 그리고 이하선 내에 종양 의 위치를 기준으로 4 가지 카테고리로 분류하는 방법을 제 안하였고 재발률이 상대적으로 낮은 WT와 재발률이 상대 적으로 높다고 알려진 $\mathrm{PA}$ 를 구분하여 양성 이하선 종양에서 $\mathrm{ECD}$ 의 적합한 적응증을 개발하고자 노력한 바 있다.

\section{$\mathrm{ECD}$ 후 타액 분비 기능에 대한 고찰}

본 교실에서는 타액선의 유속을 측정하여 수술 전 및 수 술 후 이하선의 기능 변화를 평가하여 PSP 및 CSP와 비교 한 $\mathrm{ECD}$ 의 안전성, 유용성 및 기능적 결과를 비교하는 연구 를 수행하였다.

2013년 6월부터 2014년 12월 사이에 이하선 천엽의 양성 종양을 주소로 내원하여 이하선 종양 절제술을 시행 받은 43 명의 성인 환자들을 대상으로 연구를 진행하였다. 연구에 
포함된 모든 환자들은 수술 전 검사로 이하선 종양에 대하 여 미세침 흡인 세포검사 또는 중심부 바늘 조직검사 및 전 산화단층촬영(computed tomography, CT)을 시행하였고 심 엽종양 및 수술 전 검사에서 악성종양의 가능성을 시사하는 소견을 보인 환자들은 제외하였다. 43 명의 환자들을 세 군으 로 분류하여 12 명의 환자에서는 $\mathrm{ECD}$ 를 15 명의 환자에서는 $\mathrm{PSP}$ 를 그리고 16 명의 환자에서는 $\mathrm{CSP}$ 를 시행하였다.

후향적인 의무기록 검토를 통하여 각 수술 군 별로 피부절 개부터 종양제거까지 걸린 시간, 수술 후 배액관을 통한 배 액량, 입원기간, 종양 절제의 적절성, 장기적인 재발 여부, 단 기적 및 장기적인 안면마비, Frey 증후군, 침샘류 등과 같은 수술 후 부작용의 발생여부 및 주관적인 수술 후 상처의 미 용적 만족도를 비교 분석하였다. 또한 수술 전 및 수술 후 평
상시 및 자극을 주었을 때 타액배출량을 측정하여 수술 군 별로 비교 분석하였다. 명목 변수의 비교 분석에는 피어슨 카 이제곱 검정 및 피셔의 정확도 검사를 시행하였고 연속 변수 의 비교 분석에는 Kruskal-Wallis, Mann-Whitney U, Wilcoxon 부호위수검사를 시행하였다.

수술 및 입원과 관련된 결과를 보면 피부절개부터 종양제거 까지 걸린 시간, 배액관의 배액량, 그리고 입원기간은 $\mathrm{ECD}$ 를 받은 환자들에서 $\mathrm{CSP}$ 를 받은 환자들보다 유의하게 적었고, $\mathrm{PSP}$ 를 받은 환자들과 비교하여 적은 경향을 보였다(Fig. 3).

종양학적 결과를 분석해 보았을 때, 종양 절제연의 경우 $\mathrm{ECD}$ 를 받은 모든 환자에서 종양의 침범이 없었으나 $\mathrm{PSP}$ 를 받은 환자 중 1 명(6.67\%) 및 $\mathrm{CSP}$ 를 받은 환자 중 2명(12.5\%) 에서 절제연에 종양이 노출된 소견을 보였다. 2 년 이상 추적

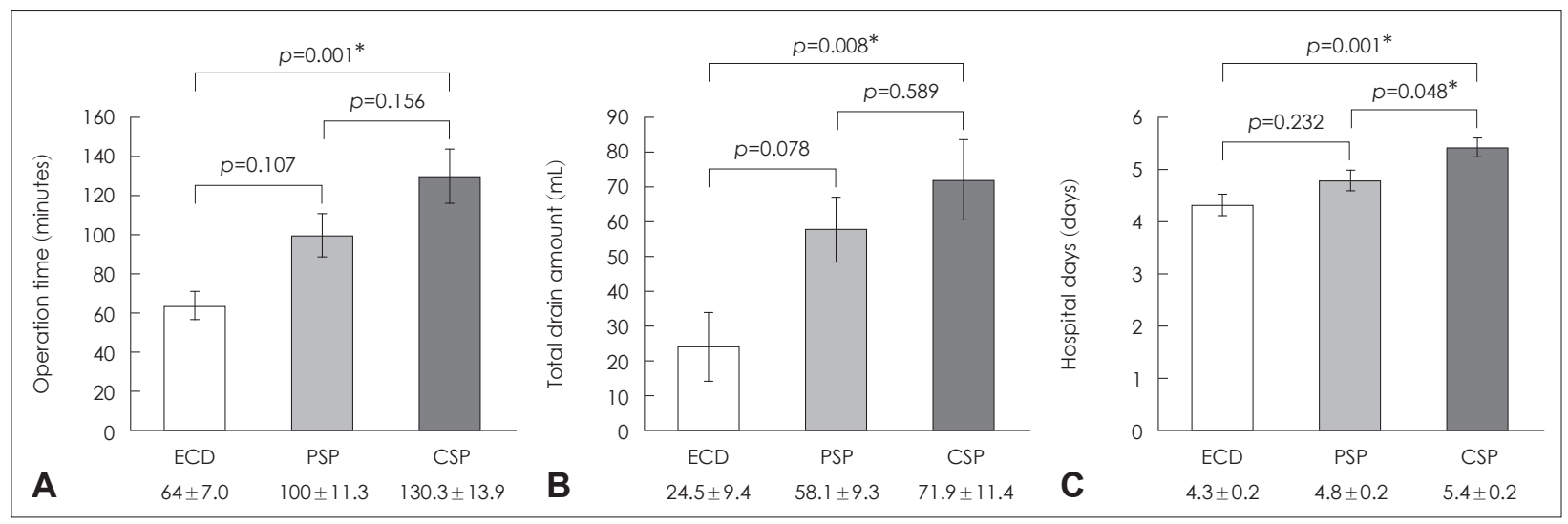

Fig. 3. Peri-operative clinical data of ECD, PSP, and CSP for tumors of the parotid gland. Operation time (minutes) (A); total amount of post-operative drainage $(\mathrm{mL})(\mathrm{B})$; total hospital stay (days) (C). *statistically significant. CSP: classic superficial parotidectomy, ECD: extracapsular dissection, PSP: partial superficial parotidectomy. Adapted from Park et al., J Oral Maxillofac Surg 2018;76(9):2004-10.19)

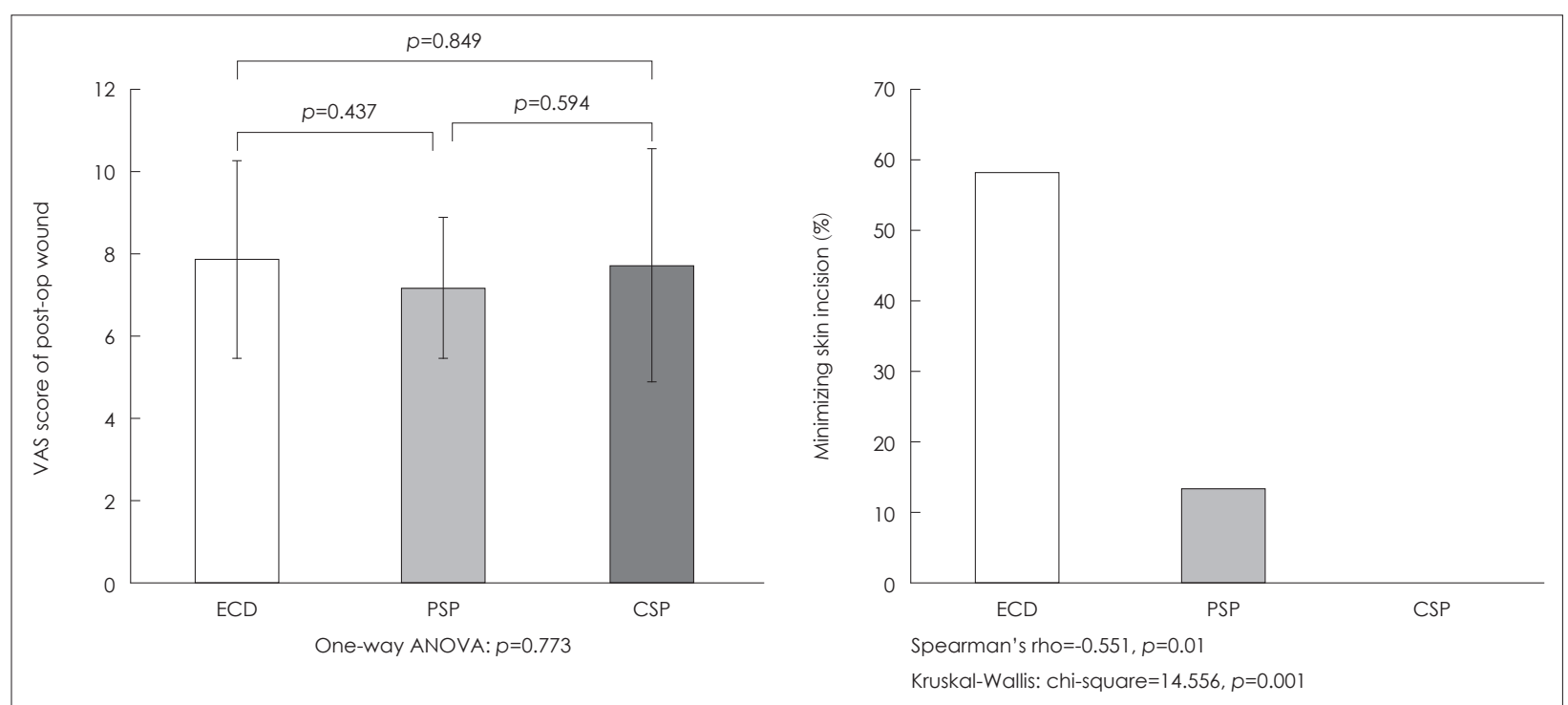

Fig. 4. Esthetic results of extracapsular dissection, partial superficial parotidectomy, and classic superficial parotidectomy for tumors of the parotid gland. VAS score for satisfaction of post-operative wounds; Percentage of patients who could minimize the skin incision rather than the modified-Blair incision. VAS: visual analogue scale, CSP: classic superficial parotidectomy. Adapted from Park et al., J Oral Maxillofac Surg 2018;76(9):2004-10. ${ }^{19}$ 
Table 1. Summary of pre- and post-operative salivary flow rate

\begin{tabular}{lcccc}
\hline & ECD & PSP & CSP & \\
& $(n=12)$ & $(n=15)$ & $(n=16)$ & -value \\
\hline Salivary flow rate $(\mathrm{mL} / \mathrm{min})^{*}$ & & & & \\
Pre-operative basal & 0.18 & 0.32 & 0.16 & 0.30 \\
Post-operative basal & 0.39 & 0.38 & 0.14 & $0.05^{\dagger}$ \\
Pre-operative stimulated & 1.11 & 1.29 & 1.69 & 0.78 \\
Post-operative stimulated & 1.02 & 1.22 & 1.02 & 0.56 \\
\hline
\end{tabular}

*kruskal-Wallis test, tstatistically significant $(p<0.05)$

CSP: classic superficial parotidectomy, ECD: extracapsular dissection, PSP: partial superficial parotidectomy. Adapted from Park SJ et al, $2018^{19)}$

관찰을 하였던 35 명의 환자들 중 $\mathrm{CSP}$ 를 받은 환자 중 1 명에 서만 수술 후 994일째 재발한 소견을 나타내었다.

수술 후 부작용 여부를 분석한 결과 단기적인 부작용을 분석해 보았을 때 일시적인 안면신경 마비, 침샘류, 그리고 Frey 증후군이 $\mathrm{ECD}$ 군에서 통계적으로 유의하지는 않았지 만 적게 발생하는 양상을 보였다. 그러나 2년 이상 추적관찰 한 환자들을 대상으로 장기적인 부작용 여부를 분석해 보았 을 때, PSP군에서 Frey 증후군이 더 많이 발생하는 경향성 을 보였으며 $\mathrm{CSP}$ 군에서만 1명의 첫 저작 증후군을 보이는 환자가 있었다.

미용적 결과를 비교해 보았을 때 2년 이상 추적 관찰한 환 자들에서 주관적인 흥터에 대한 만족도는 수술 군별 유의한 차이를 보이지 않았으나 $\mathrm{ECD}$ 군에서 흥터를 최소화할 수 있 는 가능성이 높았던 것으로 나타났다(Fig. 4).

타액 분비와 관련된 기능적 결과를 비교 분석해 본 결과 수술 전 평상 시 및 자극 후 타액 분비량과 수술 후 자극 후 타액 분비량은 수술군 별로 차이를 보이지 않았다. 그러나 수술 후 평상 시 타액 분비량의 경우 수술군 간에 유의한 차 이를 보였으며 수술 전후 자극 후 타액 분비량의 변화 정도 를 비교해 보았을 때 $\mathrm{ECD}$ 와 PSP군에서는 차이를 보이지 않 았으나 CSP군에서는 감소하는 양상을 보였다(Table 1).

\section{결 론}

$\mathrm{ECD}$ 는 안전하고 효율적인 이하선 양성 종양 절제술이며 수술 후 조기 회복을 제공한다. CSP에 비해 ECD 및 PSP를 시행한 경우 타액 기능의 보존을 통한 이하선 절제술 후 환 자의 삶의 질 향상에 도움이 될 수 있다. $\mathrm{ECD}$ 는 이하선의 양 성 종양, 특히 이하선 꼬리 부위 종양을 제거할 경우 적극적 으로 고려되어야 하겠다.

\section{Acknowledgments}

This article is based on the previous existing paper published by the authors and it was reconstructed in accordance with the intention of the readers of this journal. ${ }^{19)}$

\section{ORCID}

Sung Joon Park

https://orcid.org/0000-0001-6370-5997

Woo-Jin Jeong

https://orcid.org/0000-0001-8577-6964

\section{REFERENCES}

1) Hugo NE, McKinney P, Griffith BH. Management of tumors of the parotid gland. Surg Clin North Am 1973;53(1):105-11.

2) Spiro RH, Koss LG, Hajdu SI, Strong EW. Tumors of minor salivary origin. A clinicopathologic study of 492 cases. Cancer 1973;31(1): 117-29.

3) Giannone N, Lo Muzio L, Politi M. Extracapsular lumpectomy and SMAS flap for benign parotid tumours: an early outcome in a small number of cases on Frey's syndrome and facial nerve dysfunction. J Craniomaxillofac Surg 2008;36(4):239-43.

4) Smith SL, Komisar A. Limited parotidectomy: the role of extracapsular dissection in parotid gland neoplasms. Laryngoscope 2007;117(7): $1163-7$.

5) Riffat F, Mahrous AK, Buchanan MA, Fish BM, Jani P. Safety of extracapsular dissection in benign superficial parotid lesions. $\mathrm{J}$ Maxillofac Oral Surg 2012;11(4):407-10.

6) Mantsopoulos K, Koch M, Klintworth N, Zenk J, Iro H. Evolution and changing trends in surgery for benign parotid tumors. Laryngoscope 2015;125(1):122-7.

7) Guntinas-Lichius O, Kick C, Klussmann JP, Jungehuelsing M, Stennert E. Pleomorphic adenoma of the parotid gland: a 13-year experience of consequent management by lateral or total parotidectomy. Eur Arch Otorhinolaryngol 2004;261(3):143-6.

8) Laccourreye H, Laccourreye O, Cauchois R, Jouffre V, Ménard M, Brasnu D. Total conservative parotidectomy for primary benign pleomorphic adenoma of the parotid gland: a 25 -year experience with 229 patients. Laryngoscope 1994;104(12):1487-94.

9) Barzan L, Pin M. Extra-capsular dissection in benign parotid tumors. Oral Oncol 2012;48(10):977-9.

10) Dell'Aversana Orabona G, Bonavolontà P, Iaconetta G, Forte R, Califano L. Surgical management of benign tumors of the parotid gland: extracapsular dissection versus superficial parotidectomy--our experience in 232 cases. J Oral Maxillofac Surg 2013;71(2):410-3.

11) Kato MG, Erkul E, Nguyen SA, Day TA, Hornig JD, Lentsch EJ, et al. Extracapsular dissection vs superficial parotidectomy of benign parotid lesions: surgical outcomes and cost-effectiveness analysis. JAMA Otolaryngol Head Neck Surg 2017;143(11):1092-7.

12) Iro H, Zenk J, Koch M, Klintworth N. Follow-up of parotid pleomorphic adenomas treated by extracapsular dissection. Head Neck 2013;35 (6):788-93.

13) Lee DH, Yoon TM, Lee JK, Lim SC. Extracapsular dissection for Warthin tumor in the tail of parotid gland. Acta Otolaryngol 2017; 137(9):1007-9.

14) Mantsopoulos K, Goncalves M, Koch M, Iro H. Extracapsular dissection for warthin tumors despite the risk of ipsilateral metachronous occurrence. Laryngoscope 2018;128(11):2521-4.

15) Foresta E, Torroni A, Di Nardo F, de Waure C, Poscia A, Gasparini G, et al. Pleomorphic adenoma and benign parotid tumors: extracapsular dissection vs superficial parotidectomy--review of literature and meta-analysis. Oral Surg Oral Med Oral Pathol Oral Radiol 2014; 117(6):663-76.

16) Xie S, Wang K, Xu H, Hua RX, Li TZ, Shan XF, et al. PRISMAextracapsular dissection versus superficial parotidectomy in treatment of benign parotid tumors: evidence from 3194 patients. Medicine (Baltimore) 2015;94(34):e1237.

17) Mantsopoulos K, Scherl C, Iro H. Investigation of arguments against properly indicated extracapsular dissection in the parotid gland. Head Neck 2017;39(3):498-502.

18) Quer M, Vander Poorten V, Takes RP, Silver CE, Boedeker CC, de 
Bree R, et al. Surgical options in benign parotid tumors: a proposal for classification. Eur Arch Otorhinolaryngol 2017;274(11):3825-36.

19) Park SJ, Han S, Lee HJ, Ahn SH, Jeong WJ. Preservation of salivary function following extracapsular dissection for tumors of the parotid gland. J Oral Maxillofac Surg 2018;76(9):2004-10.

\section{정답 및 해설}

답 (3)

해 설 (1) 흔한 균은 헤모필루스 인플루엔자균(Haemophilus influenzae)

(2) 성인보다 소아에서 기도폐쇄가 잘 발생한다.

(4) 기관삽관시 통상 24-48시간 정도 유지한다.

(5) 항생제는 2세대와 3세대 세팔로스포린 계열을 주로 사용한다.

참고문헌: 대한이비인후과학회. 이비인후과학. 파주: 군자출판사;2018. p.939. 